\title{
Hubungan Kausalitas antara Kinerja Sosial dan Ekonomi Perusahaan
}

\author{
Paulina Permatasari \\ Universitas Katolik Parahyangan Bandung \\ Jl. Ciumbuleuit No. 94 Bandung 40141 \\ E-Mail:paulina@unpar.ac.id/paulinapssj@gmail.com
}

\begin{abstract}
The purpose of this study is to investigate the causality of relationship between the corporate economic performance and corporate social performance and also to get a picture about disclosure of Corporate Social Reporting (CSR) performance of companies in Indonesia that have deployed and published Standalone Sustainability Reports, and/or has disclosed Social and Environmental Responsibility or Sustainability in Annual Report, and the company website. The variables used to measure corporate economic performance are company size, profitability, leverage, and growth. The corporate social performance is measured by using an CSR disclosure index. The Causality relationship between corporate economic and social performance is based on the Slack Resource Theory and Good Management Theory. As the pilot study, a sample of 34 companies listed on JSX is taken using stratified random sampling method with 2010 data as the focus of the report analysis. The result of this study shows that there's no significant relationship between Corporate Economic and Corporate Social Performance. The study also shows the low level of corporate disclosure of CSR.
\end{abstract}

Keywords: corporate social performance, corporate economic performance, company size, profitability, leverage, growth.

\begin{abstract}
ABSTRAK
Tujuan penelitian ini adalah untuk menginvestigasi hubungan kausalitas antara kinerja ekonomi dengan kinerja sosial perusahaan. Selain itu, tujuan penelitian ini adalah untuk mendapatkan gambaran mengenai pengungkapan kinerja sosial dari perusahaan-perusahaan di Indonesia yang telah menerapkan dan mempublikasikan Laporan Berkelanjutan yang terpisah dan ataupun perusahaan yang telah mengungkapkan tanggung jawab. sosial dan lingkungan atau berkelanjutan dalam laporan tahunannya ataupun dalam website perusahaan. Metode analisa konten diaplikasikan untuk menganalisa laporan tahunan perusahaan. Variabel yang digunakan untuk mengukur kinerja ekonomi perusahaan adalah ukuran perusahaan, profitabilitas, leverage, dan pertumbuhan. Kinerja sosial perusahaan diukur dengan menggunakan indeks pengungkapan tanggung jawab sosial korporasi. Sebagai studi pendahuluan, diambil sampel 34 perusahaan dari perusahaan yang terdaftar di Bursa Efek Indonesia, dengan data tahun 2010 sebagai focus analisa. Hasil penelitian ini menunjukkan bahwa tidak terdapat hubungan signifikan antara kinerja ekonomi dan kinerja sosial disamping menunjukkan seberapa jauh tingkat pengungkapan pelaporan tanggung jawab sosial perusahaan.
\end{abstract}

Kata Kunci: kinerja sosial perusahaan, kinerja ekonomi perusahaan, ukuran perusahaan, profitabilitas, leverage, pertumbuhan. 


\section{PENDAHULUAN}

Secara tradisional, setiap perusahaan menerbitkan laporan keuangan tahunan untuk mengkomunikasikan kinerja keuangan mereka. Namun informasi yang tersaji dalam laporan keuangan tidak dapat memenuhi semuai informasi yang dibutuhkan oleh para pemangku kepentingan khususnya yang berkaitan dengan aspek non keuangan. Dengan tujuan untuk memenuhi kebutuhan para pemangku kepentingan, hampir selama sepuluh tahun terakhir ini telah dibentuk suatu usaha untuk mengembangkan apa yang disebut dengan Pelaporan Kinerja Sosial (Corporate Social Reporting atau CSR) atau Pelaporan Berkelanjutan (Sustainability Reporting).

Pelaporan berkelanjutan ditujukan untuk mengkomunikasikan kinerja ekonomi, sosial dan lingkungan atau yang disebut dengan 'The Triple Bottom Line Reporting'. Kinerja sosial dan lingkungan sering disebut pertanggungjawaban sosial korporasi atau Corporate Social Responsibility (CSR). Global Reporting Initiative (2006) mendefinisikan pelaporan berkelanjutan sebagai suatu praktik pengukuran, pengungkapan dan akuntabilitas bagi pemangku kepentingan internal dan eksternal terkait kinerja organisasi yang mengarah pada pencapaian tujuan pengembangan berkelanjutan.

Perkembangan bentuk Pelaporan Berkelanjutan telah berevolusi dari sekedar pengungkapan dalam satu bentuk paragraf sederhana pada laporan tahunan perusahaan hingga berbentuk suatu laporan khusus yang berdiri sendiri yang dikeluarkan oleh perusahaan yang berisi informasi mengenai kinerja lingkungan dan social perusahaan. Kebanyakan Pelaporan Berkelanjutan yang dibuat perusahaan hanyalah berupa pelengkap atas laporan tahunan yang dibuat bagi pemegang saham untuk dibawa dalam rapat tahunan pemegang saham. Namun hanya sedikit perusahaan yang sudah membuat dan mempublikasikan Laporan Berkelanjutan mereka secara tersendiri (stand-alone sustainability report). Dibandingkan dengan keseluruhan perusahaan yang sudah terdaftar di Bursa Efek Indonesia proporsinya hanyalah $2.87 \%, 4.88 \%, 5.91 \%, 6.2 \%$, dan $6.9 \%$ di tahun 2006, 2007, 2008, 2009, dan 2010.

Dengan tren perkembangan yang positif serta meningkatnya kualitas pelaporan itu merupakan gambaran peningkatan kesadaran akan pentingnya CSR di kalangan perusahaan di Indonesia terlebih untuk perusahaan agrikultur dan pertambangan. Usaha untuk mempromosikan Pelaporan Berkelanjutan dilakukan oleh Ikatan Akuntan Manajemen Indonesia (IAMI) melalui pemberian penghargaan Indonesia Sustainability Reporting Awards (ISRA). Selain itu juga terdapat usaha pemerintah untuk mengatur implementasi kegiatan CSR melalui Undang-Undang No. 25 tahun 2007 mengenai Penanaman Modal dan Undang-Undang No. 40 tahun 2007 mengenai Perseroan Terbatas, di mana praktik CSR menjadi suatu mandate bagi perusahaan yang berhubungan dengan sumber daya alam dimana hal ini juga berdampak bagi motivasi untuk pelaporan berkelanjutan (Report of the Judge - ISRA, 2010).

Sustainability Report penting untuk mengevaluasi kinerja ekonomi, sosial, dan lingkungan serta untuk mengarahkan kegiatan operasional serta untuk menyediakan informasi mengenai tantangan dan pencapaian bagi pemegang saham, karyawan serta publik dan pemangku kepentingan lainnya. Ini dapat berfungsi sebagai bukti akan adanya komitmen internal terkait tanggung jawab lingkungan dan sosial serta sebagai alat pemasaran perusahaan yang dikaitkan dengan strategi bisnis perusahaan yang menelusuri perkembangan upaya mengintegrasikan prinsip sustainability dengan program dan rencana perusahaan. Telah banyak penelitian yang meneliti bagaimana perusahaan-perusahaan di dunia telah melakukan Sustainability Reporting dalam pelaporannya (Gray et al., 1995, Hedberg dan von Malmborg 2003, Holcomb et al., 2007, Kolk, 2003, Lober et al., 1997, Raman 2006, Rikhardsson et al., 2002, Vormedal, I. dan A. Ruud. 2006).

Pada saat ini, pelanggan dan pemangku kepentingan lainnya menaruh harapan besar pada perusahaan-perusahaan agar mereka melaporkan kegiatan yang berhubungan dengan CSR (Isaksson dan Steimle, 2009). Para manajer dan perusahan tersebut merasa perlu untuk menjalankan proses pelaporan berkelanjutan ini selain karena adanya tekanan dari berbagai pihak internal seperti berbagai kelompok manajer yang berbeda maupun tekanan dari publik, media, pemangku kepentingan, politik, dan pasar, juga karena adanya bebagai kesempatan seperti kesempatan untuk memiliki reputasi, persaingan maupun kesempatan di pasar (Burritt dan Schaltegger, 2010). Lebih lanjut, berkembangnya pelaporan CSR telah mengarah pada berbagai studi berkaitan dengan pelaporan maupun pengungkapan CSR yang terutama bertujuan untuk mengevaluasi kinerja sosial perusahaan dan menemukan karakteristik yang menjadi ciri khas suatu perusahaan dari program CSR mereka. 
Dalam pembuatan laporan tersebut seringkali mengacu pada prinsip yang disusun oleh organisasi global, salah satunya yaitu Global Reporting Index (GRI) yang diharapkan dapat mengurangi ketidakkonsistenan dalam penyampaian informasi dalam Pelaporan Berkelanjutan. Beberapa studi sebelumnya menemukan bahwa kualitas informasi dan isi pelaporan itu bergantung pada beberapa variabel diantaranya adalah skala perusahaan serta kelompok industri serta indikator keuangan lainnya. Oleh karenanya dalam hal ini menjadi sangat penting untuk mengevaluasi sejauh mana keterkaitan kinerja sosial dengan kinerja keuangan serta mengidentifikasi bagaimana hubungan antara Pelaporan Berkelanjutan dan aktivitas CSR dengan kinerjakeuangan perusahaan (Idowu dan Towler, 2004; Gunawan, 2007; Mirfazli, 2008; Sawani et al., 2010; Byus et al., 2010; Veronica et al., 2010; Gao, 2011).

Mengestimasi value yang dihasilkan dari kegiatan sustainability merupakan hal yang penting untuk memahami secara komprehensif proses pengambilan keputusan dalam perusahaan. Jika sustainability dijadikan sebagai suatu bagian dari strategi perusahaan maka hendaknya dipertimbangkan dalam kaitannya bagaimana hal ini dapat berkontribusi terhadap strategi perusahaan. Untuk mengestimasi besarnya penilaian moneter untuk sustainability, sebagai suatu manfaat dari adanya aktivitas ekonomi, dalam hal ini digunakan beberapa ukuran financial yang merefleksikan kinerja keuangan dari perusahaan. Dalam menilai hubungan antara kinerja CSR dan kinerja keuangan perusahaan, Fauzi (2009) menemukan bahwa gambaran hubungan ini perlu dilakukan dengan menggunakan model yang terintegrasi sebagaimana diungkapkan dalam berbagai literatur akuntansi dan manajemen strategi serta dengan mempertimbangkan contingency variable seperti lingkungan bisnis, strategi bisnis, struktur organisasi ,dan sistem pengendalian terhadap kinerja perusahaan dalam konteks Triple Bottom Line. Di samping itu, hubungan antara kinerja CSR dan kinerja keuangan mencakup dua hal penting yaitu direction dan causality of the relationship (Fauzi, 2009). The direction dari hubungan itu mengarah pada hubungan positif, negatif, dan netral sedangkan untuk causality dari hubungan itu menggambarkan bahwa salah satu dari kinerja CSR dan kinerja keuangan akan menjadi variabel dependen atau independen.

Mengacu pada penelitian-penelitian sebelumnya serta mengembangkannya untuk periode tahun yang terkini khususnya sejalan dengan perkembangan makin banyaknya perusahaan di Indonesia yang menerbitkan Stand Alone Sustainability Report maka fokus penelitian ini ditujukan untuk melihat gambaran dari pengungkapan CSR serta mengivestigasi hubungan kausalitas antara pengungkapan CSR dengan kinerja ekonomi perusahaan dari sisi skala perusahaan yang diwakili dengan ukuran Total Assets, profitabilitas yang diukur menggunakan ukuran Return on Asset (ROA), besarnya pengaruh kreditur yang diukur dengan Leverage Ratio serta Growth Opportunity yang diukur dengan rasio Market Value to Book Value of Equity.

Penelitian ini diharapkan dapat memberikan kontribusi bagi literatur CSR khususnya mengenai perkembangan pengungkapan CSR di Indonesia yang mana menunjukkan makin banyaknya perusahaan yang membuat Stand Alone CSR Report. Selain itu penelitian ini juga memperkaya penelitian sebelumnya yaitu dengan memasukkan variabel growth opportunity yang sepanjang pengetahuan peneliti, belum pernah diteliti untuk kasus perusahaanperusahaan di Indonesia. Dalam hal ini sangat penting untuk memasukkan bagaimana pengaruh dari adanya growth opportunity untuk pelaporan CSR sejalan dengan meningkatnya 'sustainability awareness trend' yang terjadi. Selain itu penelitian ini juga mengeksplorasi bagaimana hubungan kausalitas antara CSR disclosure and Corporate Financial Performance akan meningkatkan manfaat bagi dunia riset di Indonesia karena masih sangat sedikitnya penelitian mengenai hal ini.

\section{METODE}

\section{Rancangan dan Kerangka Penelitian}

Penelitian ini merupakan penelitian kuantitatif. Data diambil dari Laporan perusahaan baik Laporan Tahunan (Annual Report (AR)) maupun Laporan Berkelanjutan (Sustainability Report (SR)), website, maupun laporan lain yang memberikan informasi tentang variabel penelitian. Pengujian yang dilakukan adalah pengujian tentang hubungan kausalitas antara variabel independen terhadap variabel dependen, baik secara parsial maupun secara simultan.

Kerangka penelitian menunjukkan bahwa kinerja perusahaan untuk kinerja ekonomi dapat mempengaruhi kinerja sosial dan sebaliknya kinerja sosial juga dapat mempengaruhi kinerja ekonomi sebagaimana tergambar dalam Gambar 1. berikut. 

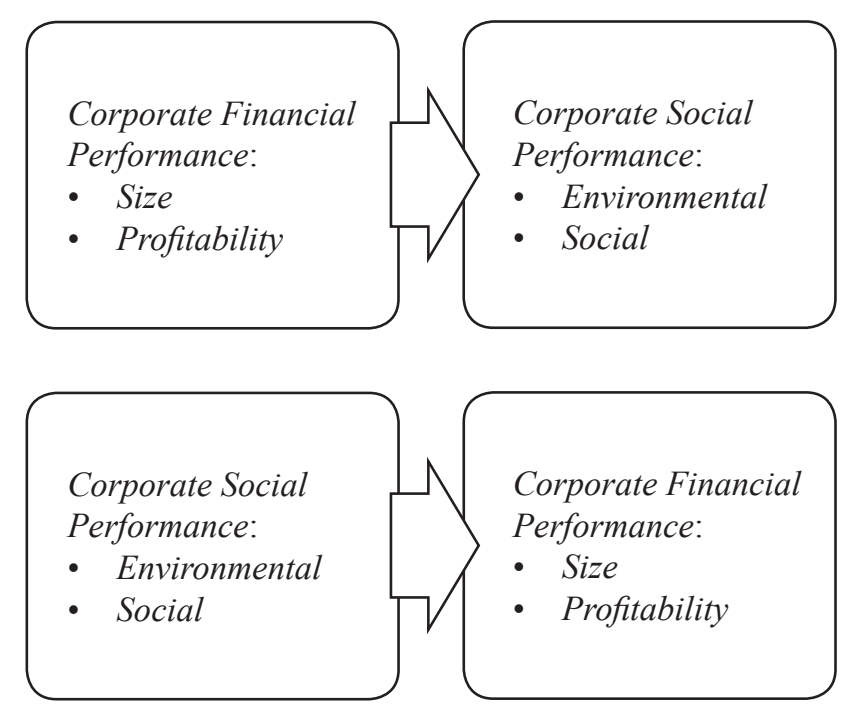

Gambar 1. Kerangka Penelitian

\section{Sample dan Pengumpulan Data}

Dalam penelitian ini, pengumpulan data dilakukan untuk memperoleh data CSR dan data kinerja keuangan dari perusahaan publik yang terdaftar di Bursa Efek Indonesia. Pengumpulan data dilakukan dengan cara mengakses website perusahaan untuk memperoleh baik CSR yang menjadi bagian dalam Laporan Tahunan maupun yang merupakan laporan tersendiri berupa Stand-Alone CSR report.

Penentuan sampel dilakukan dengan cara purposive sampling (judgement sampling) yaitu sampel diambil berdasarkan kriteria tertentu. Kriteria pengambilan sampelnya meliputi (a) perusahaan terdaftar di Bursa Efek Indonesia pada tahun 2010, (b) laporan Keuangan tahun 2010 telah diaudit oleh akuntan publik dan telah dipublikasikan pada masyarakat melalui website www.idx.co.id atau website perusahaan, dan (c) perusahaan mengungkapkan penjelasan yang memadai tentang Corporate Social Responsibility.

Penelitian ini dilakukan pada 34 perusahaan publik yang terdaftar di Bursa Efek Indonesia dalam upaya memenuhi jumlah minimum sampel sebanyak 30 sebagaimana Uma Sekaran (2010) menyampaikan rules of thumb terkait penentuan jumlah sampel. Penelitian dengan jumlah sampel yang lebih banyak akan memberikan kontribusi yang lebih baik dalam upaya "menggeneralisasi" hasil penelitian

\section{Hipotesis Penelitian}

Berdasarkan Slack resource Theory, perusahaan harus memiliki posisi keuangan yang baik untuk berkontribusi dengan kinerja sosial perusahaan. Melakukan kinerja sosial membutuhkan dana yang dihasilkan dari keberhasilan kinerja keuangan. Menurut teori ini, kinerja keuangan yang lebih dulu. Oleh karena itu, Kinerja Keuangan Perusahaan adalah variabel independen untuk mempengaruhi Kinerja Sosial Perusahaan (Fauzi, 2009).

Good Management Theory menyatakan bahwa kinerja sosial yang muncul pertama. Berdasarkan teori ini, kinerja sosial perusahaan adalah variabel independen sehingga menghasilkan Kinerja Keuangan Perusahaan dan reputasi perusahaan yang baik akan dirasakan oleh para pemegang saham maka akan membuat perusahaan lebih mudah untuk mendapatkan posisi keuangan yang baik. Atas dasar ini selanjutnya dikembangkan hipotesis penelitian sebagai berikut:

H1 : Skala Perusahaan mempunyai pengaruh yang signifikan terhadap Sustainability Reporting Level

$\mathrm{H} 2$ : Sustainability Reporting Level mempunyai pengaruh yang signifikan terhadap Skala Perusahaan

H3 : Profitabilitas mempunyai pengaruh yang signifikan terhadap Sustainability Reporting Level

H4: Sustainability Reporting Level mempunyai pengaruh yang signifikan terhadap Profitabilitas

H5 : Tingkat Leverage mempunyai pengaruh yang signifikan terhadap Sustainability Reporting Level

H6: Sustainability Reporting Level mempunyai pengaruh yang signifikan terhadap Tingkat Leverage

H7 : Growth Opportunity mempunyai pengaruh yang signifikan terhadap Sustainability Reporting Level

H8: Sustainability Reporting Level mempunyai pengaruh yang signifikan terhadap Growth Opportunity

H9: Skala Perusahaan, ROA, Tingkat Leverage, Growth Opportunity secara bersama-sama mempunyai pengaruh yang signifikan terhadap Sustainability Reporting Level 


\section{Model Analisis Data}

Dalam penelitian ini digunakan model regresi untuk menggambarkan hubungan kausalitas antara kelima variabel sebagaimana dibahas sebelumnya. Untuk pengujian hipotesis pertama, ketiga, kelima dan ketujuh digunakan Model Simple Regresion sebagai berikut:

$\mathrm{SUSR}=\beta 0+\beta 1 \mathrm{SIZE}$

$\mathrm{SUSR}=\beta 0+\beta 1$ PROFIT

SUSR $=\beta 0+\beta 1$ LEVERAGE

\section{$\mathrm{SUSR}=\beta 0+\beta 1$ GROWTH}

Pengujian hipotesis kedua, keempat, keenam dan kedelapan digunakan Model Simple Regresion sebagai berikut:

$\mathrm{SIZE}=\beta 0+\beta 1 \mathrm{SUSR}$

PROFIT $=\beta 0+\beta 1$ SUSR

LEVERAGE $=\beta 0+\beta 1 \mathrm{SUSR}$

GROWTH $=\beta 0+\beta 1$ SUSR

Untuk pengujian hipotesis kesembilan digunakan model Multiple Regression sebagai berikut: $\mathrm{SUSR}=\beta 0+\beta 1 \mathrm{SIZE}+\beta 2 \mathrm{PROFIT}+\beta 3 \mathrm{LEV}+$

$$
\beta 4 \text { GROWTH }
$$

di mana:

SUSR $=$ sustainability reporting index

SIZE $=$ total assets

PROFIT $($ PROFITABILITY $)=$ return on assets,

LEVERAGE $=$ debt to equity ratio

GROWTH = market value to book value of equity

Sebelum dilakukan analisis regresi tersebut, data yang telah dikumpulkan terlebih dahulu dilakukan Uji Asumsi Klasik.

\section{HASIL}

\section{Hasil Pengujian Statistik}

Berkaitan hasil pengujian statistik atas hipotesa pertama, ketiga, kelima dan ketujuh diperoleh hasil seperti disajikan pada Tabel 3. Hasil pengujian statistik untuk hipotesis kedua, keempat, keenam dan kedelapan disajikan pada Tabel 4., sedangkan pengujian statistik untuk hipotesis kesembilan dapat dilihat pada Tabel 5 .
Tabel 3. Statistik Deskriptif untuk Variabel TA, ROA, LEVERAGE, GROWTH sebagai Variabel Independen dan SUSR sebagai Variabel Dependen

\begin{tabular}{lcrrrrr}
\hline $\begin{array}{c}\text { Variabel X } \\
\text { (Independen) }\end{array}$ & $\mathbf{R}^{\mathbf{2}}$ & Constant & $\begin{array}{c}\text { Koefisien } \\
\text { Beta }\end{array}$ & t-value & Sig \\
\hline TA & 0.012 & 75.556 & -0.109 & -0.622 & 0.538 \\
ROA & 0.041 & 64.312 & 0.203 & 1.172 & 0.25 \\
Leverage & 0.112 & 82.474 & -0.335 & -2.012 & 0.053 \\
Growth & 0.043 & 76.769 & -0.207 & -1.197 & 0.24 \\
\hline
\end{tabular}

Tabel 4. Statistik Deskriptif untuk Variabel SUSR sebagai Variabel Independen dan TA, ROA, LEVERAGE, GROWTH sebagai Variabel Dependen

\begin{tabular}{lrrrrrr}
\hline $\begin{array}{l}\text { Variabel Y } \\
\text { (Dependen) }\end{array}$ & $\mathbf{R}^{2}$ & Constant & $\begin{array}{c}\text { Koefisien } \\
\text { Beta }\end{array}$ & t-value & Sig \\
\hline TA & 0.012 & $9.024 \mathrm{E} 13$ & -0.109 & -0.622 & 0.538 \\
ROA & 0.041 & 0.076 & 0.203 & 1.172 & 0.25 \\
Leverage & 0.112 & 3.563 & -0.335 & -2.012 & 0.053 \\
Growth & 0.043 & 10.083 & -0.207 & -1.197 & 0.24 \\
\hline
\end{tabular}

Tabel 5. Statistik Deskriptif untuk Variabel TA, ROA, LEVERAGE, GROWTH sebagai Variabel Independen dan SUSR sebagai Variabel Dependen untuk Pengujian Secara Simultan

\begin{tabular}{lrrr}
\hline \multicolumn{1}{c}{ Variabel } & Koefisien Beta & \multicolumn{1}{c}{ t-value } & \multicolumn{1}{c}{ Sig } \\
\hline Constant & & 5.785 & 0.000 \\
TA & 0.109 & 0.544 & 0.591 \\
ROA & 0.184 & 0.902 & 0.374 \\
Leverage & -0.340 & -1.573 & 0.127 \\
Growth & -0.300 & -1.678 & 0.104 \\
\hline
\end{tabular}

Hasil regresi sebagaimana terlihat pada Tabel 3. dan Tabel 4. menunjukkan bahwa tidak terdapat hubungan yang signifikan antara Skala perusahaan dalam hal ini diukur dengan Total Asset karena $p$-value nya lebih besar dari pada 0,05 . Hasil ini menunjukkan bahwa Total asset tidak berperan dalam menentukan tingkat pengungkapan dalam Sustainability Reporting, dengan demikian terlihat bahwa hasil penelitian ini tidak mendukung hipotesis pertama dan kedua dan berarti skala perusahaan tidak mempunyai pengaruh 
terhadap Sustainability Reporting Level dan demikian pula sebaliknya Sustainability Reporting Level tidak mempunyai pengaruh terhadap skala perusahaan.

\section{Hasil pengujian antara Variabel Profitabilitas dengan Sustainability Reporting Level}

Hasil regresi sebagaimana terlihat pada Tabel 3. dan Tabel 4. menunjukkan bahwa tidak terdapat hubungan yang signifikan antara Profitabilitas dalam hal ini diukur dengan Return on Asset (ROA) karena p-value nya lebih besar dari pada 0,05 . Hasil ini menunjukkan bahwa ROA tidak berperan dalam Sustainability Reporting, dengan demikian terlihat bahwa hasil penelitian ini tidak mendukung hipotesis ketiga dan keempat dan berarti Profitabilitas tidak mempunyai pengaruh terhadap Sustainability Reporting Level dan demikian pula sebaliknya Sustainability Reporting Level tidak mempunyai pengaruh terhadap Profitabilitas.

\section{Hasil pengujian antara Variabel Tingkat Leverage dengan Sustainability Reporting Level}

Hasil regresi sebagaimana terlihat pada Tabel 3 . dan Tabel 4. menunjukkan bahwa terdapat hubungan yang signifikan antara tingkat leverage dalam hal ini diukur dengan rasio total debt dibagi total equity karena $p$-value nya sama dengan 0,05 . Hasil ini menunjukkan bahwa tingkat leverage berperan dalam Sustainability Reporting, dengan demikian terlihat bahwa hasil penelitian ini mendukung hipotesis kelima dan keenam dan berarti tingkat leverage mempunyai pengaruh terhadap Sustainability Reporting Level dan sebaliknya Sustainability Reporting Level tidak mempunyai pengaruh terhadap tingkat leverage.

\section{Hasil Pengujian antara Variabel Growth Opportunity dengan Sustainability Reporting Level}

Hasil regresi sebagaimana terlihat pada Tabel 3. dan Tabel 4. menunjukkan bahwa tidak terdapat hubungan yang signifikan antara Growth Opportunity dalam hal ini diukur dengan rasio Market Value terhadap Book Value of Equity karena p-value-nya lebih besar dari pada 0,05. Hasil ini menunjukkan bahwa Growth tidak berperan dalam Sustainability Reporting, dengan demikian terlihat bahwa hasil penelitian ini tidak mendukung hipotesis ketujuh dan kedelapan dan berarti Growth Opportunity tidak mempunyai pengaruh terhadap Sustainability Reporting Level dan demikian pula sebaliknya
Sustainability Reporting Level tidak mempunyai pengaruh terhadap Growth Opportunity.

Hasil Pengujian antara Variabel Skala Perusahaan, Profitabilitas, Tingkat Leverage, dan Growth Opportunity dengan Sustainability Reporting Level

Hasil regresi sebagaimana terlihat pada Tabel 5. menunjukkan bahwa tidak terdapat hubungan yang signifikan antara Skala Perusahaan, Profitabilitas, Tingkat Leverage dan Growth Opportunity dengan Sustainability Reporting Level karena p-value-nya lebih besar dari pada 0,05 . Hasil ini menunjukkan bahwa keempat variabel ini tidak berperan dalam Sustainability Reporting, dengan demikian terlihat bahwa hasil penelitian ini tidak mendukung hipotesis kesembilan dan berarti Skala Perusahaan, Profitabilitas, Tingkat Leverage serta Growth Opportunity tidak mempunyai pengaruh terhadap Sustainability Reporting Level.

\section{PEMBAHASAN}

Hasil penelitian menunjukkan bahwa skala perusahaan tidak berpengaruh terhadap Sustainability Reporting Level meskipun dalam penelitian sebelumnya skala perusahaan memainkan peranan penting dalam menentukan seberapa jauh tingkat pengungkapan CSR karena perusahaan-perusahaan besar umumnya sangat menekankan nama baik perusahaan dan biasanya menggunakan sustainability reporting sebagai suatu alat untuk mendapatkan status di kalangan masyarakat serta reputasi yang baik. Namun sayangnya hasil penelitian ini tidak sejalan dengan studi sebelumnya kemungkinan dikarenakan terlalu sedikitnya sampel yang digunakan sebagai objek penelitian.

Dalam riset sebelumnya oleh Atiase (1985) ditemukan bahwa perusahaan yang lebih besar dengan kinerja keuangan yang lebih baik memiliki dorongan yang lebih tinggi untuk mengungkapkan informasi. Selain itu sesuai dengan hipotesis political (Watts dan Zimmerman 1986) yang menyatakan bahwa perusahaan yang lebih besar menarik perhatian media massa, pembuat kebijakan dan regulator lebih banyak. Oleh karena itu mereka berada pada kondisi tekanan yang lebih besar untuk berkinerja lebih baik khususnya berkaitan sustainability.

Hasil penelitian juga menunjukkan bahwa profitabilitas tidak berpengaruh terhadap Sustainability 
Reporting Level karena mungkin saja perusahaan yang memiliki profit tinggi salah satunya disebabkan dilakukannya berbagai upaya menekan pengeluaran yang berhubungan dengan kegiatan CSR. Jika mengacu pada penelitian lainnya terkait hubungan antara Corporate Social Performance dan Corporate Financial Performance (McWilliams dan Siegel, 2000) yang menunjukkan bahwa hubungan antara CSR dengan profitability memiliki arah hubungan yang tidak tentu, dapat berhubungan positif, negatif, atau netral. Arah positif dari hubungan ini adalah bahwa peningkatan kinerja perusahaan dari sisi sosial meningkatkan kinerja keuangan perusahaan, sedangkan perubahan kinerja sosial perusahaan yang mengarah ke perubahan kinerja keuangan perusahaan dalam hal sebaliknya mengakibatkan hubungan yang negatif. Jika perubahan kinerja sosial perusahaan tidak mempengaruhi perubahan dalam kinerja keuangan perusahaan, efek netral arah hubungan akan terjadi. Sebagai contoh, misalnya hasil penelitian Wright dan Ferris (1997) menunujukkan adanya hubungan negatif antara CSR dengan kinerja keuangan perusahaan. Sebaliknya penelitian Posnikoff (1997) melaporkan adanya hubungan positif antara CSR dan kinerja keuangan. Sementara itu penelitian Teoh et al. (1999) menemukan bahwa tidak ada hubungan antara CSR dan kinerja keuangan perusahaan.

Meskipun dalam penelitian lainnya menemukan bahwa profitabilitas memainkan peranan penting dalam menentukan seberapa jauh tingkat pengungkapan CSR karena perusahaan-perusahaan besar umumnya sangat menekankan nama baik perusahaan dan biasanya menggunakan sustainability reporting sebagai suatu alat untuk mendapatkan profit (Dilling, 2010; Michael Cortez dan Cynthia P., 2011; Sawani et al., 2010). Dengan kata lain, ini menjadi sulit untuk disimpulkan dengan pasti terkait hubungan antara Profitabilitas dan Sustainability disclosure level.

Dalam tahun 1992 studi yang dilakukan oleh Roberts (1992) menyimpulkan bahwa perusahaan dengan kinerja operasi yang lebih baik memiliki kemungkinan untuk memliki dorongan lebih tinggi untuk membuat pengungkapan lingkungan yang lebih mendetail karena mereka mampu untuk memiliki dana lebih banyak yang dicadangkan untuk kegiatan yang berhubungan dengan lingkungan. Dalam kondisi ini, perusahaan yang memiliki kinerja ekonomi lebih baik diharapkan mampu untuk mengungkapkan lebih pada hal-hal yang berhubungan dengan pengembangan berkelanjutan (sustainable development). Hasil penelitian menunjukkan bahwa terdapat hubungan yang signifikan antara tingkat leverage dengan sustainability reporting level. Sustainability reporting seringkali mencakup proses pengumpulan dan analisis data atas penggunaan sumber daya serta material yang digunakan serta assessment atas proses bisnis. Proses ini dapat membantu investor untuk mengidentifikasi kesempatan-kesempatan yang ada untuk melakukan penghematan biaya ataupun penambahan revenue melalui penggunaan sumber daya dan material secara lebih efisien. Peningkatan jumlah investor ataupun kreditur mencakup juga pertimbangan berkelanjutan dalam proses pengambilan keputusan. Informasi yang berhubungan dengan sustainability dapat membantu investor ataupun kreditor untuk menentukan faktor risiko yang dihubungkan dengan praktik bisnis perusahaan. Contohnya mereka mungkin tertarik dengan proyek khusus atau aktivitas bisnis lainnya yang berhubungan dengan pengembangan berkelanjutan dalam perusahaan-perusahaan di mana mereka berinvestasi. Tekanan ini dengan demikian telah meningkatkan pentingnya untuk meningkatkan upaya pengungkapan semua issue yang berhubungan dengan sustainability.

Dalam penelitian mengenai pengungkapan sustainability (Leftwich et al., 1981) berargumen bahwa permintaan atas informasi akan meningkat saat perusahaan memiliki hutang yang meningkat. Hal ini disebabkan karena kreditur memberikan tekanan pada perusahaan untuk mengungkapkan informasi mengenai lingkungan ataupun yang berhubungan dengan sosial terkait dengan akses atas kemungkinan hutang yang terjadi di masa yang akan datang. Dengan demikian diharapkan bahwa pada perusahaan yang memiliki hutang makin banyak dalam struktur permodalan mereka maka pengungkapan atas lingkungan maupun sosial perlu lebih terbuka. Namun jika mengacu pada penelitian lainnya sebagaimana telah diuraikan sebelumnya terkait hubungan antara Corporate Social Performance dan Corporate Financial Performance memiliki dua isu penting: arah dan hubungan kausalitas (Fauzi, 2009). Arah hubungan mengacu positif, negatif, dan hubungan netral. Arah positif dari hubungan ini adalah bahwa peningkatan kinerja perusahaan dari sisi sosial meningkatkan kinerja keuangan perusahaan, sedangkan perubahan kinerja sosial perusahaan yang mengarah ke perubahan kinerja keuangan perusahaan 
dalam hal sebaliknya mengakibatkan hubungan yang negatif. Jika perubahan kinerja sosial perusahaan tidak mempengaruhi perubahan dalam kinerja keuangan perusahaan, efek netral arah hubungan akan terjadi.

Selain itu hasil penelitian ini menunjukkan bahwa tidak terdapat hubungan antara growth opportunity dan the sustainability disclosure. Harga pasar ekuitas terhadap nilai buku ekuitas merupakan suatu indikator mengenai berapa banyak pemegang saham bersedia membayar atas aset bersih perusahaan. Meskipun sustainability reporting sangatlah penting dalam pertumbuhan jangka panjang perusahaan, hubungan yang kurang ini ditemukan dapat menyebabkan kurang berkembangnya pertumbuhan sustainability reporting. Selain itu, para pemangku kepentingan mungkin menerima tingkat prioritas sustainability reporting yang berbeda-beda antar perusahaan. Investor seringkali belum menganggap sustainability reporting sebagai faktor penting ketika melakukan pengambilan keputusan investasi, mereka seringkali mengambil keputusan investasi dengan lebih mendasarkan pada kinerja keuangan. Hasil penelitian ini sejalan dengan hasil penelitian yang dilakukan oleh Adams (2010) yang meneliti bagaimana hubungan antara indeks harga saham dengan sustainability report, dengan hasil penelitian menunjukkan bahwa tidak ada pengaruh signifikan sustainability reporting terhadap perubahan harga saham perusahaan yang terdaftar di Dow Jones Sustainability Index.

Secara umum diharapkan bahwa dengan pertumbuhan yang lebih baik, perusahaan cenderung untuk melakukan usaha lebih banyak berkaitan dengan peningkatan tingkat pengungkapan. Para pemangku kepentingan dapat membandingkan kinerja dalam perusahaan dengan di luar perusahaan dari waktu ke waktu. Dengan pertumbuhan yang lebih tinggi, maka usaha yang lebih banyak juga dilakukan bagi para pemangku kepentingan (Fukyi, 2010). Namun jika mengacu pada penelitian lainnya sebagaimana telah diuraikan sebelumnya terkait hubungan antara Corporate Social Performance dan Corporate Financial Performance memiliki dua isu penting: arah dan hubungan kausalitas (Fauzi, 2009). Arah hubungan mengacu positif, negatif, dan hubungan netral. Arah positif dari hubungan ini adalah bahwa peningkatan kinerja perusahaan dari sisi sosial meningkatkan kinerja keuangan perusahaan, sedangkan perubahan kinerja sosial perusahaan yang mengarah ke perubahan kinerja keuangan perusahaan dalam hal sebaliknya mengakibatkan hubungan yang negatif. Jika perubahan kinerja sosial perusahaan tidak mempengaruhi perubahan dalam kinerja keuangan perusahaan, efek netral arah hubungan akan terjadi.

Dari pembahasan di atas, dapat dilihat bahwa hasil penelitian ini tidak dapat menunjukkan adanya hubungan kausalitas kelima variabel penelitian sebagaimana dinyatakan dalam Slack Resource Theory dan Good Management Theory yang ditujukan untuk menguji hubungan kausalitas antara kinerja sosial dengan kinerja ekonomi perusahaan .

Hasil penelitian juga menunjukkan mengenai masih rendahnya tingkat pengungkapan yang berhubungan dengan CSR atau Sustainability di Indonesia yang terutama disebabkan belum diwajibkannya semua perusahaan yang terdaftar di Bursa Efek Indonesia untuk mengungkapkan semua kegiatan yang berhubungan dengan CSR atau Sustainability yang dilakukan oleh perusahaan mereka. Selain itu jika dilihat dari perusahaan-perusahaan yang sudah mencantumkan pengungkapan CSR atau Sustainability dalam Laporan Tahunan mereka ataupun dalam Stand Alone Sustainability Report, indikator dan aspek lingkungan maupun sosial yang diungkapkan masih belum selengkap panduan yang ada (GRI - Global Reporting Index) karena penggunaan standar ini masih bersifat voluntary.

\section{KESIMPULAN}

Hasil penelitian menunjukkan bahwa tingkat Leverage memiliki pengaruh terhadap Sustainability Reporting Level dan demikian sebaliknya Sustainability Reporting Level memiliki pengaruh pula terhadap tingkat Leverage. Namun untuk hasil penelitian terkait Skala Perusahaan, Profitabilitas dan Growth Opportunity, ketiganya serta untuk pengujian keempat variabel secara bersama-sama tidak menunjukkan adanya pengaruh yang signifikan. Hasil ini tidak sejalan dengan penelitian-penelitian sebelumnya yang menemukan bahwa terdapat pengaruh signifikan dengan Sustainability Reporting Level baik hubungan positif maupun negatif. Tidak sejalannya hasil penelitian ini dengan penelitianpenelitian sebelumnya kemungkinan disebabkan terlalu sedikitnya jumlah sampel yang digunakan.

Hasil penelitian juga menunjukkan mengenai masih rendahnya tingkat pengungkapan yang berhubungan dengan CSR atau Sustainability di Indonesia yang terutama disebabkan belum 
diwajibkannya semua perusahaan yang terdaftar di Bursa Efek Indonesia untuk mengungkapkan semua kegiatan yang berhubungan dengan CSR atau Sustainability yang dilakukan oleh perusahaan mereka. Selain itu jika dilihat dari perusahaan-perusahaan yang sudah mencantumkan pengungkapan CSR atau Sustainability dalam Laporan Tahunan mereka ataupun dalam Stand Alone Sustainability Report, indikator dan aspek lingkungan maupun sosial yang diungkapkan masihlah belum selengkap panduan yang ada (GRI - Global Reporting Index) karena penggunaan standar ini masih bersifat voluntary.

\section{DAFTAR PUSTAKA}

Adam, Michael, Thorton, Barry, and Sepehri, Mohammad. 2010. The impact of the Pursuit of Sustainability on the Financial Performance of the Firm. Journal of Sustainability and Green Business, (Oktober).

Atiase, R. K. 1985. Predisclosure Information, Firm Capitalization, and Security Price Behavior Around Earnings Announcements. Journal of Accounting Research, 23(1): 21-36.

Burritt, Roger L. and Schaltegger, Stevan. 2010. Sustainability Accounting and Reporting: Fad or Trend?. Accounting, Auditing \& Accountability Journal, 23 (7): 829-846.

Byus, Kent. Deis, Donald and Quyang, Bo. 2010. Doing Well by Doing Good: Corporate Social Responsibility and Profitability. Advanced Management Journal, 75(1): 44-55.

Dilling, Petra F. A. 2010. Sustainability Reporting In A Global Context: What Are The Characteristics Of Corporations That Provide High Quality Sustainability Reports - An Empirical Analysis. International Business \& Economics Research Journal, 9(1): 19-30.

Fauzi, Hasan. 2009. The Determinants of the Relationship of Corporate Social Performance and Financial Performance: Conceptual Framework.

Fukyi, Tang and Kayu, Chan. 2010. Research on Sustainability in Indonesia.

Gao, Yongqiang. 2011. CSR in an Emerging Country: A Content Analysis of CSR Reports of Listed Companies. Baltic Journal of Management, 6(2): 263-291.

Global Reporting Initiative. 2002. Sustainability Reporting Guidelines, Global Reporting Initiative - GRI, Boston, MA.
Global Reporting Initiative. 2006. Sustainability Reporting Guidelines, Global Reporting Initiative - GRI, Amsterdam.

Gray, R., R. Kouhy and S. Lavers. 1995. Corporate Social Environmental Reporting: A Review of Literature and Longitudinal Study of UK Disclosure. Accouting, Auditing, \& Accountability Journal, 8(2): 47-77.

Gunawan, Juniati. 2007. Corporate Social Disclosures by Indonesian Listed Companies: A Pilot Study. Social Responsibility Journal, 3(3): 26.

Gunawan, Juniati. 2010. Perception of important information in corporate social disclosures: Evidence from Indonesia. Social Responsibility Journal, 6(1): 62-71.

Hedberg, C. J. and von Malmborg, F. 2003. The Global Reporting Initiative and Corporate Sustainability Reporting in Swedish Companies. Corporate Social Responsibility and Environmental Management, 10: 153-64.

Holcomb, J. L., Upchurch, R. S. and Okumus, F. 2007. Corporate Social Responsibility: What are Top Hotel Companies Reporting?. International JournalofContemporaryHospitality Management, 19(6): 461-475.

Idowu, S. O. and Towler, B. A. 2004. A Comparative Study of The Contents of Corporate Social Responsibility Reports of UK Companies. Management of Environmental Quality: An International Journal, 15(4): 420-37.

Idowu, S. O. and Papasolomou, I. 2007. Are the Corporate Social Responsibility Matters Based on Good Intentions or False Pretences? An Empirical Study of the Motivations Behind the Issuing of CSR Reports by UK companies. Corporate Governance, 7(2): 136-47.

Isaksson, Raine and Steimle, Ulrich. 2009. What Does GRI-Reporting Tell Us About Corporate Sustainability?. The TQM Journal, 21(2): 168181.

Kolk, A. 2003. Trends in Sustainability Reporting by the Fortune Global 250. Business Strategy and the Environment, 12(5): 279-91.

Krut, R. and A. Moretz. 2000. The State of Global Environmental Reporting: Lesson from the Global 100. Environmental Reporting, 7(1): 85-91.

Leftwich, R. W., Watts, R. L., \& Zimmerman, J. L. 1981. Voluntary Corporate Disclosure: The Case of Interim Reporting. Journal of Accounting Research, 18, 50-77. 
Lober, D., D. Bynum, E. Campbell and M. Jacques. 1997. The 100 plus Corporate Environmental Report Study: A Survey of an Evolving Environmental Management Tool. Business Strategy and the Environment, 6(2): 57--73.

Michael, Angelo A., Cortez and Cynthia, Cudia. 2011. Sustainability and Firm Performance: A Case Study of Japanese Electronics Companies. Ritsumeukan International Affairs, 10: 321-337.

McWilliams, Abagail and Siegel, Donald. 2000. Corporate Social Responsibility and Financial Performance: Correlation or Misspecification? Strategic Management Journal, 21(5): 603-609.

Mirfazli, Edwin. 2008. Evaluate Corporate Social Responsibility Disclosure at Annual Report Companies in Multifarious Gorup of Industry Members of JSX, Indonesia. Social Responsibility Journal, 4(3): 388-406.

Posnikoff, J. F. 1997. Disinvestment from South Africa: They did Well by Doing Good. Contemporary Economic Policy, 15(1): 76-86.

Raman, S. 2006. Corporate Social Reporting in IndiaA View from the Top. Global Business Review, 7(2): 313

Rikhardsson, P., A. Andersen and H. Bang. 2002. Sustainability Reporting on the Internet: A Study of the Global Fortune 500. Green Management International, 40(Winter): 57-75.

Roberts, R. W. 1992. Determinants of Corporate Social Responsibility Disclosure: An Application of Stakeholder Theory. Accounting, Organization and Society, 17, 595-612.
Sawani, Yussri., Mohamed Zain, Mustaffa, and Darus, Faizah. 2010. Preliminary Insights on Sustainability Reporting and Assurance Practices in Malaysia. Social Responsibility Journal, 6(4): 627-645.

Sekaran, Uma. 2010. Research Methods for Business: A Skill Building Approach ( $5^{\text {th }}$ edition). New York: John Wiley \& Sons.

Teoh, S. H., I. Welch and C. P. Wazzan. 1999. The effect of socially activist investment policies on the financial markets: Evidence from the South African boycott. Journal of Business, 72(1): 3589.

Veronica Siregar, Sylvia and Bachtiar, Yanivi. 2010. Corporate Social Reporting: Empirical Evidence from Indonesia Stock Exchange. International Journal of Islamic and Middle Eastern Finance and Management, 3(3): 241252.

Vormedal, I. and A. Ruud. 2006. Sustainability Reporting in Norway: An Assessment of Nonfinancial Disclosures by the 100 Largest Firms. Business Strategy and the Environment, 18(4): 207-22.

Watts, R. L., and Zimmerman, J. L. 1986. Positive accounting theory. Englewood Cliffs. New Jersey: Prentice Hall.

Wright, P. and S. Ferris. 1997. Agency Conflict and Corporate Strategy: The Effect of Divestment on Corporate Value. Strategic Management Journal, 18(1): 77-83. 